\title{
NK-631（Pepleomycin）の肺機能に及ばす影響
}

\author{
小谷順一郎・川居日出夫・坐馬隆明: 中条昭博
}

中田茂樹・杉浦慧治・金田敏郎・小泉朋久*

\section{Effects of NK-631 (Pepleomycin) on pulmonary function}

\author{
Junichiro KotanI - Hideo KaWAJIRI - Takaaki Zanma \\ Akihiro Chujo - Shigeki Nakata $\cdot$ Kenji Sugiura \\ Toshio KANEDA - Akihisa Kolzumi*
}

\section{緒言}

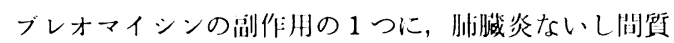

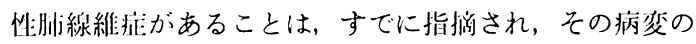
成り立ちについては，かなりの跟皆がみられる1 7)。 のよらに，臨术においてブレオマイシン仯用が致命的肬 障害を惹起しかねない場合もあるので，その発生を早期
に予知したり，孙防する目的で，ブレオマイシン投与後 の纱機能の变化に肺障㫪の指䧣を求めようとする試みが 種々なされてきた7 13). 今回，われわれは，ブレオマイ

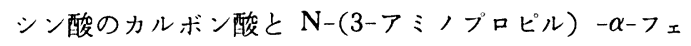
ネチルアミンの一級アミノ基を脱水縮合したブレオマイ シン誘導体の硫酸塩である NK-631 (Pepleomycin) (図

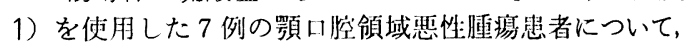
経時的に条種帅機能検查および胸部X線写真の撮影を行<smiles>CCNC(=O)c1csc(-c2csc(CNC(=O)C(NC(=O)C(C)C(O)C(C)NC(=O)C(NC(=O)c3nc(C(CC(N)=O)NCC(N)C(N)=O)nc(N)c3C)c3cnc[nH]3)C(O)C(O)CO)n2)n1</smiles>

図 1 NK-631 の化学㩐造

名古屋大学医学部口腔外科学杪坐（主任：阔迹 教授)

*富山市民病院㴹科（主任：小泉明久）

Department of Oral Surgery, Nagoya University

School of Medicine (Chief: Prof. Tohru Oka)

*Department of Dental Clinic, Toyama Municipal Hospital (Chicf: Akihisa Koizumi)

受付日：沼和54年 2 月 19 日

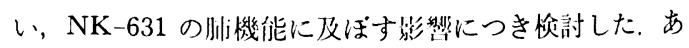
わせて，本剂の副作用によると思われる怘性肺炎で死亡 した 1 例を経験したので，その湖剖検所見について報告 する.

\section{対象ならびに検查方法}

㞸和152年10月より，㮌和153年 3 月までに，NK-631 単 
表 1 対象症例

\begin{tabular}{|c|c|c|c|c|c|c|}
\hline 症例 & 氏名 & 年龄 & 性別 & 䛦 & \begin{tabular}{|l|}
$\mathrm{NK}-631$ \\
投与線量
\end{tabular} & 投与才法 \\
\hline 1. & & 47 & 男 & 舌癌 & $254.5 \mathrm{mg}$ & $\begin{aligned} \text { I. } & \text { V } \\
& \rightarrow \text { I. A }\end{aligned}$ \\
\hline 2. & & 71 & 女 & 下䫇肉腫 & $286.5 \mathrm{mg}$ & I. $\begin{aligned} & \mathrm{V}(\times 6) \\
& \rightarrow \mathrm{I} \cdot \mathrm{A} .\end{aligned}$ \\
\hline 3. & & 68 & 男 & 口唇癌 & $232 \mathrm{mg}$ & I. $\begin{aligned} & \text { ( } \\
& \rightarrow \mathrm{I} \cdot \mathrm{A})\end{aligned}$ \\
\hline 4. & & 69 & 男 & 口峡咽頭癌 & $220 \mathrm{mg}$ & I. $\begin{aligned} & V(\times 5) \\
& \rightarrow \mathrm{I} \cdot \mathrm{A} .\end{aligned}$ \\
\hline 5. & & 54 & 男 & 下顎瘦 & $200 \mathrm{mg}$ & I. A. \\
\hline 6. & & 28 & 女 & 口底瘦 & $200 \mathrm{mg}$ & I. $\begin{aligned} & \mathrm{V}(\times 2) \\
& \rightarrow \mathrm{I} \cdot \mathrm{A} .\end{aligned}$ \\
\hline 7. & & 68 & 女 & 煩粘膜癌 & $200 \mathrm{mg}$ & $\begin{aligned} \text { I. } & \text { V } \\
& (\times 3) \\
& \rightarrow \text { I.A. }\end{aligned}$ \\
\hline
\end{tabular}

表 2 肺機能検查

肺 活 量 vital capacity (VC)

比肺活量 \%vital capacity (\%VC)

最大换気量 maximal voluntary ventilation (MVV)

1 秒 率 forced expiratory volume 1.0/vital

一酸化炭素肺胞拻散能力 (DLCO)

独で治療した例数は11例である，その中で，腫瘍の発生 部位や，口内炎の関係で，肺機能検查が技術的に困難で あったり，得られたデータに信頼性がないと思われる4 例を除く 7 例について検討した。 また，本剂投与症例で 急性肺炎を発症して死亡した 1 例を経験したが，これは 治療中の肺機能検査は行われていないので， 7 例とは別 個に，剖倹所見を主として後述する。7症例の一覧は， 表 1 に示すとおりで，症例はすべて新䰻一次症例で，口

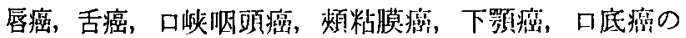

それぞれ 1 例ずつ計 6 例の扁平上皮癌と，下䫇線維肉腫 の 1 例である，性別は，男 4 例，女 3 例，28藏の症例を 除きその他は40歳以上で，平均57.9歳であった。全症例 とも投与前の胸部X線写真では加路的変化とみられる所 胃以外の異橖は認められなかった，NK-631 の投与方㳎 は，原則として抄続動注法により投与したが，確定診断 のための病理組織片採取の時点や，入院前の待機期間中 に one shot 婙注を行ったので，静注が先行した症例が 6 例あった。業注は 1 回 $10 \mathrm{mg}$ を one shot に週 3 回と し，その回数は表 1 に示すと㧍りである，動註は，想 侧浅側頭動脈より逆行珄に catheter を挿入し，投与最 は1 日 $5 \mathrm{mg}$ ，持続動注器 (Sharp infusion pump. model PIP-21) により投与した，NK-631 の全投与量は200mg 〜254. 5mg であり平均 $227.6 \mathrm{mg}$ であった，同時併用楽 は urokinase $6000 \mathrm{U} /$ day, heparin $1000 \mathrm{U} /$ day を使用し たが，肺線維症予防のためのステロイド投与などは一切 行わず，NK-631 単独投与による肺機能の変化を検討し た。

肺機能検查の内容は，表 2 に示すごとく， BenedictRoth 型 spirometor で, 肺活量 (vital capacity, VC), 比肺活量 ( \% vital capacity, \% VC), 最大換気量 (maximum voluntary ventilation, MVV), および 1 秒量 (forced expiratory volume 1.0, FEV1.0) より 1 秒率 (FEV1.0/VC) を計测し，かつ肺の線維化を比校的早 期にとらえるといわれる一酸化炭素肺胞拡散能力 (dif fusion capacity, DLco)を CO breath holding technique にて测定し検討した。胸部X線罕真は备症例とも10日〜 14日に 1 回の割合で据影したが，症例により肺機能検湘 候の変化度が異なり，その候㧍よび隍林症状に応じ撮影 回数が変わっているので，必ずしも全症例とも同時期に 报影されているとは限らない，また，肺機能愉查の第 1

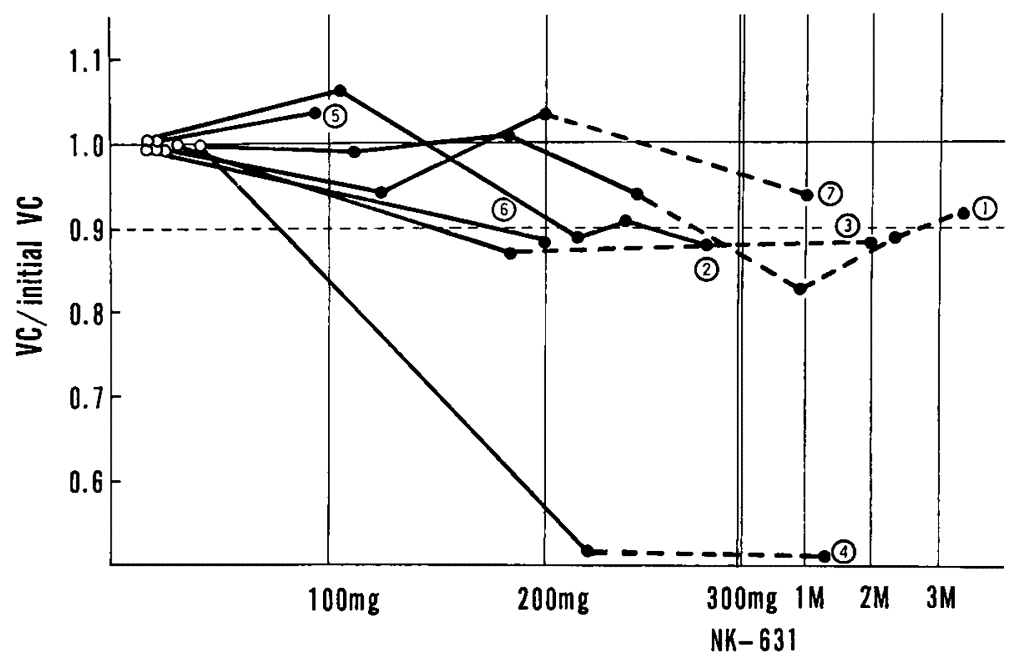

図 2 肺活量/初回肺活量比の経時的変化 
回目の测定は NK-631 10 20mg 使用後のものがほと んどで，使用前の値を得ることはできなかったが，その 変化率の変動をもって評価した，すなわち第 1 回目測定 値より90\%以下に低下した樦合を悪化と判定した。

\section{成 績}

\section{肺活量 (VC) (図 2)}

図 2 に第 1 回目测定の肺活量に対する経時的な変化率 を示す，縱軸に変化率，涉軸に NK-631 の量および使 用終了後の月数を言し, 実線は使用中の, 破線は使用終 了後の変化を示す，变化率が $10 \%$ 箱囲内にあるものは 2 例（症例 5,7 ）で，他の 5 例は $10 \%$ 以上低下した。 特に 症例 4 は $220 \mathrm{mg}$ 使用終了時点で，初回測定値の $50.6 \%$ まで低下した

\section{最大換気量 (MVV)（図3）}

MVV 測定には，患者にかなりの肉体的負担がかか り，特に，われわれの対象とした老人はその負荷に耐え ることが不可能なことがあることや，口腔癌の場合は病 変の部位にマウスピースを装着せねばならない関保から 問題となるため，われわれの症例でも 3 例（症例 $1,2,6$ ) しか测定できなかった．結果は 1 例（症例 6) のみが74 \%の低下で, 他の 2 例は10\%簌团内の変化にとどまっ た。

比肺活量（\%VC）および1秒率（FEV1.0/VC）（図 $4,5)$

図 4 に\% VC，すなわち测定肺活虽が，その個人の身長 より算出した漯潐肺活昂の何％に当たるかを裴したもの で，この值の変化摔は，肺活唯とほぼ同じ变化をとり， これも 7 例中 5 例に $10 \%$ 以上の低下がみられた。これに

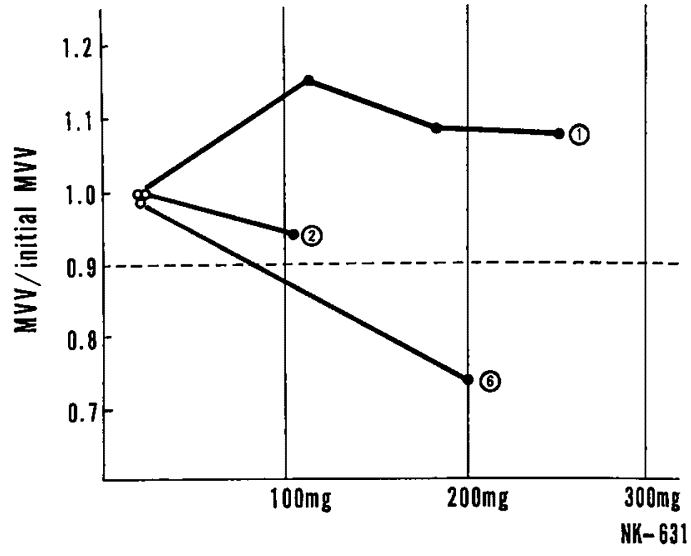

図 3 最大換気量/初回最大换気量比の経時的変化

反し，最大吸気位から最初の1秒間の呼気がス量が，実 测肺活量の何\%に当たるかを示した1秒率 (FEV1.0/ VC) (図 5) は, $95 \mathrm{mg}$ 時点で測定した 1 例（症例 5) を除き 6 例が10\%箐围内の変化にとどまっている。 この ことは肺の閉塞性因子には影響せず, 拘束性障害度の增 悪傾向があることを示唆するものである。

\section{拡散能 (DLCO)（図 6)}

6 例につき検索したが（症例 5 を除く）おのおのの 最終值の変化率は, 症例 6 を除き, $10 \%$ 以上低下し, 特 に症例 4 は36. $4 \%$ まで下がった，この症例は前述の VC が最も低下したものと同一例であるが，他の症例も\%肺 活量の变化と相閂して低下している。たたしDLcoの 測定に関しては，NK-631 を100mg 以上使用した時点 で初回测定を行ったものが 3 例あり, 使用前からの变化

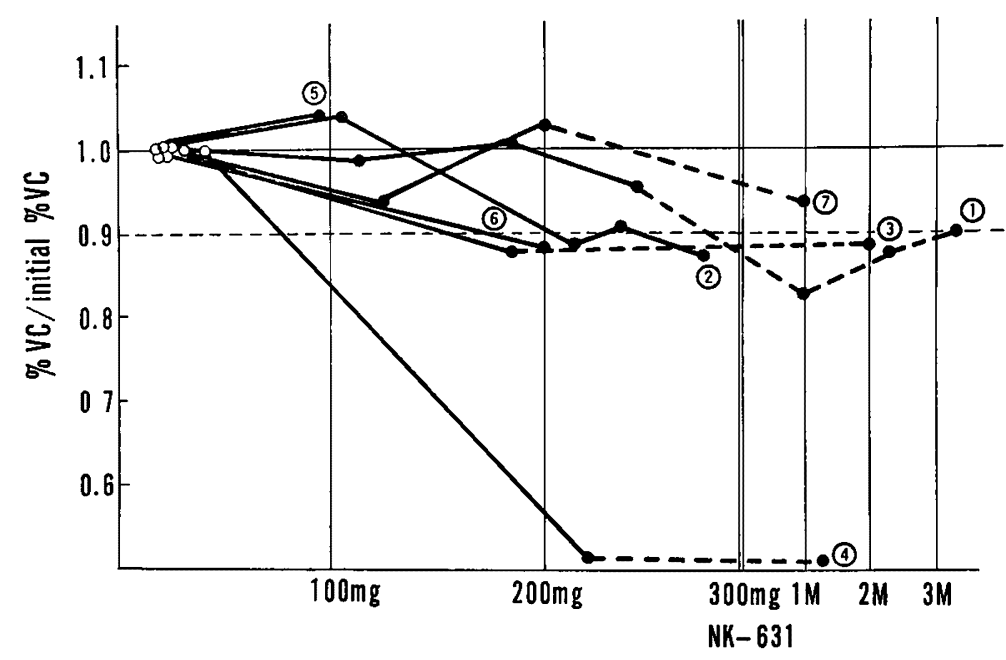

図 4 比肺活量/初回比肺活量比の経時的変化 


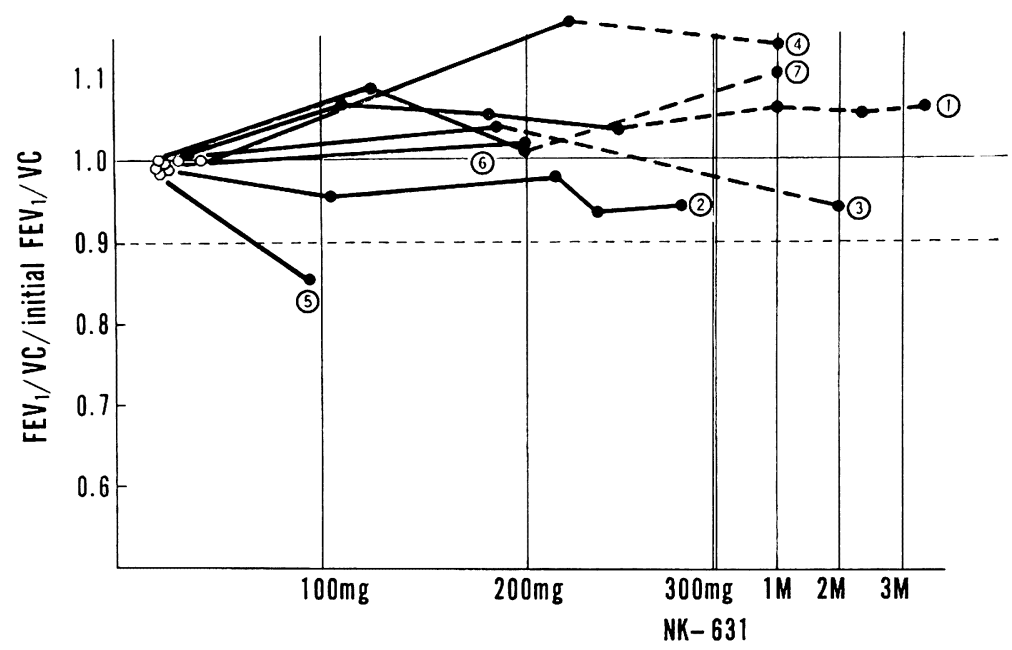

図 51 秒率/初回 1 秒染比の経腙的変化

表 3 症例 4 (E. K. 69y) の抎散能（DLCO）の変化

\begin{tabular}{c|r|r|r}
\hline & $15 / \mathrm{XII}$ & \multicolumn{1}{|c}{$30 / \mathrm{I}$} & \multicolumn{1}{c}{$28 / \mathrm{II}$} \\
\hline $\begin{array}{c}\text { Dico }(\mathrm{m} / \mathrm{min} . / \mathrm{mmHg}) \\
\text { Obs./Pred. } \\
\text { dose }\end{array}$ & 9.9 & 5.2 & 3.6 \\
& $40 \mathrm{mg}$ & $220 \mathrm{mg}$ & 40 日後 \\
\hline
\end{tabular}

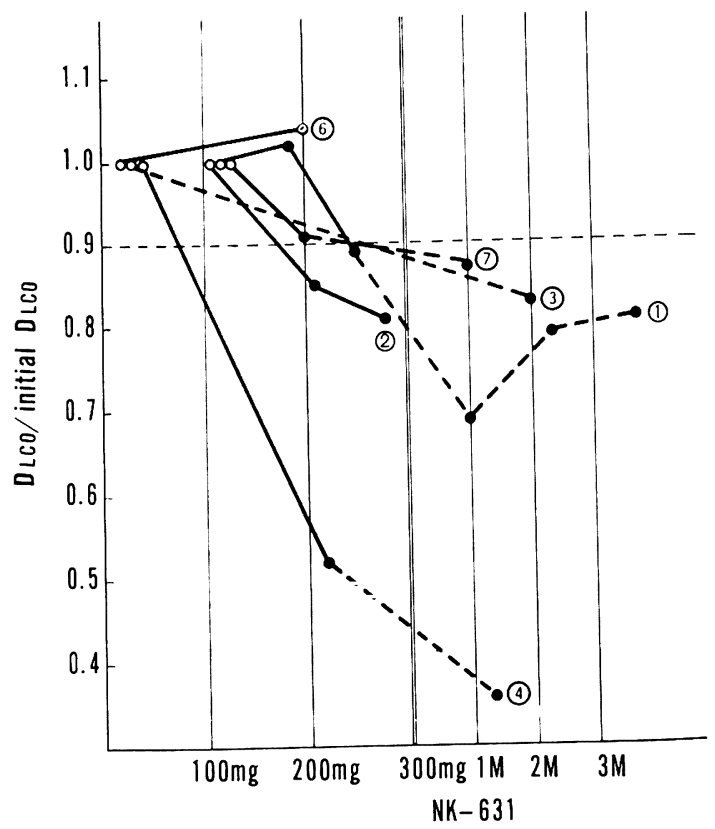

図 6 払散能/初回払散能比の経時的変化

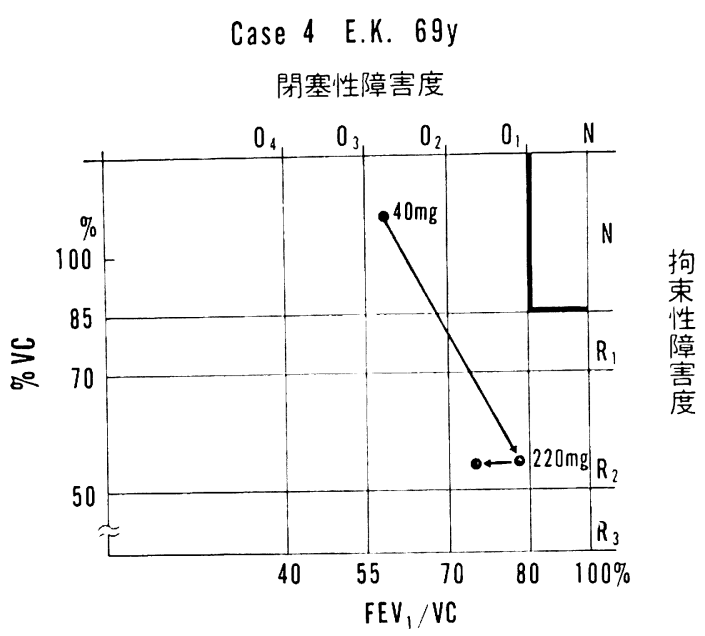

図 7 症例 4 の比肺活量と 1 秒染の相対的 变化走示与

浐はさらに大きくなる可能性がある。この点から考える とDLCo が他の肺父量分画よりも鋭敏に反応している といえる。

以上の結果よりみると閉塞性障害度を表す FEV1.0/

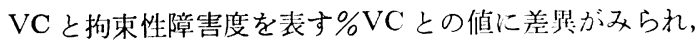
肺機能愉查测定上の問題点を考㤫しても, 拘束性障害が 若起していることがらかがわれる。

次に，前述した VC，\%VC，Dlco が著明に低下した 症例 4 について述べる。症例は69藏, 男性, 口峡咽预部 癌で計 $220 \mathrm{mg}$ （狰注 $50 \mathrm{mg}$, 䟚注 $170 \mathrm{mg}$ ）投与した。表 3 のごとくDLCo の第 1 回目测定は $40 \mathrm{mg}$ 使用時点で 行われたが，この洔すでに $9.9 \mathrm{ml} / \mathrm{min} / \mathrm{mmHg}$ と予测优 


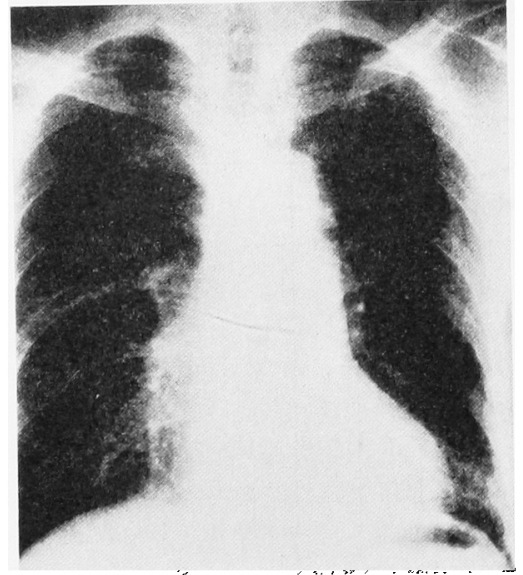

写真 $1 \mathrm{NK}-631,170 \mathrm{mg}$ 使用時点の胸部 $\mathrm{X}$ 線等真，左下肺野にびまん性險 影が出現。

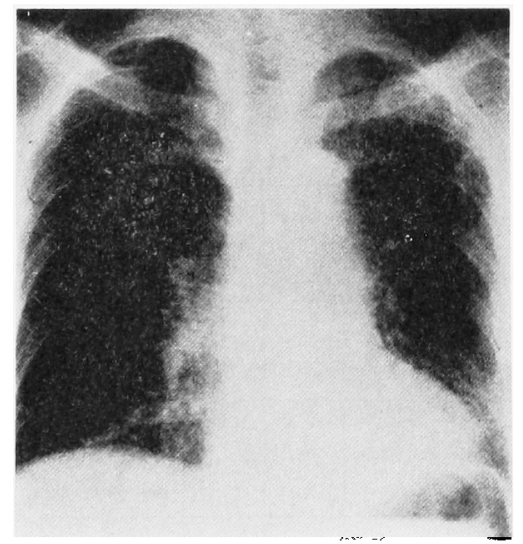

写真 2 NK-631 釉了後 1 か月目の胸部X 線写真，两肺にわたり，網状，小 班:状除影を認める。

との比率は69\%で，かなり低い值をとりすでに肺内で の alveolar capillary block が推起できるが, 220mg 俌 用時には $5.2 \mathrm{ml} / \mathrm{min} / \mathrm{mmHg}(37 \%)$ ，使用終了後 40 日 で $3.6 \mathrm{ml} / \mathrm{min} / \mathrm{mmHg}(25 \%)$ と進行性に低下している ことがかかる。また，図７のことく閉塞性障害度をあら わす FEV1.0/VC の低下に比べ，拘束性障害度を示す \%VC が大きく低下し， fibrosis 発生を裏付计ている。 胸部X線写真上では写真 1 にみられるよらに $170 \mathrm{mg}$ 使 用時点で撮影したもの以後に，左下师野に diffuse な除 影が現れた，写真 2 は，作用終了後 1 か月目のものであ るが，雨肺にわたり絧状，小琣状陰影が認められた。な お，この陰影は 4 か月後にも残存し，不可逆性の变化で あることがわかった。なお，本例の呼吸器系の臨床症状 は，上記の検査所見に此べると軽度で，胸部X線写真上

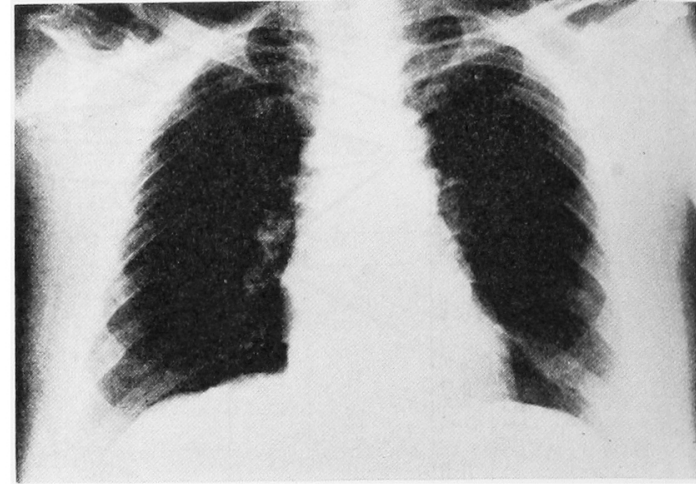

写真 3 肺炎にて死亡した症例の治療前胸 部X線写真．写真上では異常はみ られない

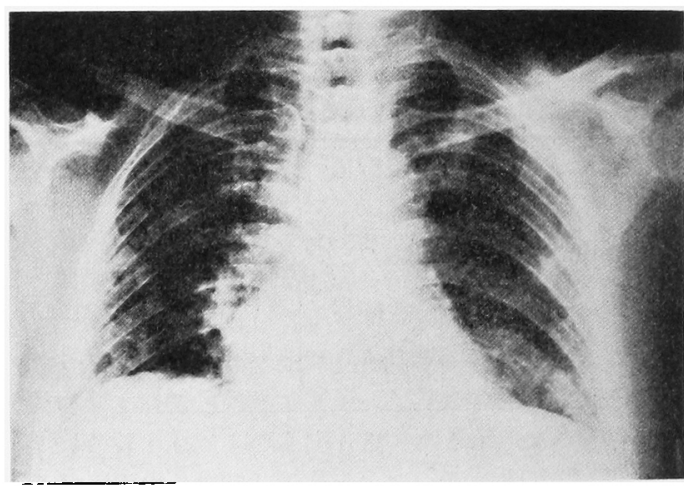

写真 $4 \mathrm{NK}-631$ 100mg 使用時点. 両側 にわたり diffuse な陰影が出現。

で陰影が壮現したのとほぼ同㭙期より，軽度の発熱，咳 などの症状が時々出琴したが，雷䈆な呼吸困難などの出 現はなかった。

\section{急性肺炎にて死亡した 1 剖検例について}

本例は，肺機能検查の follow up を行っていないので 前述のデータの中には含まれていないが，都検により肪 の所見を確認した，症例は 67 歳，女性， $\mathrm{T}_{3} \mathrm{~N}_{1 \mathrm{a}}$ Moの 下顎癌 (squamous cell ca.) で, 静注 $80 \mathrm{mg}$ 動注 $20 \mathrm{mg}$ (計100 mg) ころより胸部X楾写真上で diffuse な陰影 が認められるよらになったか゚ (写真 3，4,5), 呼吸器系の 巽常な臨床症状を欠いていたので投薬を継続した。 220 $\mathrm{mg}$ 投与後，恶心，逼吐， $39^{\circ} \mathrm{C}$ の発熱が出現，投蒋を 中止したが，さらに高熱と呼吸困難が持芜して種々の抗 炎症治療を行ったにもかかわらず肺炎にて死亡した。な お，本症例は治療前の既往歴に呼四器系の疾患はなかっ た. 


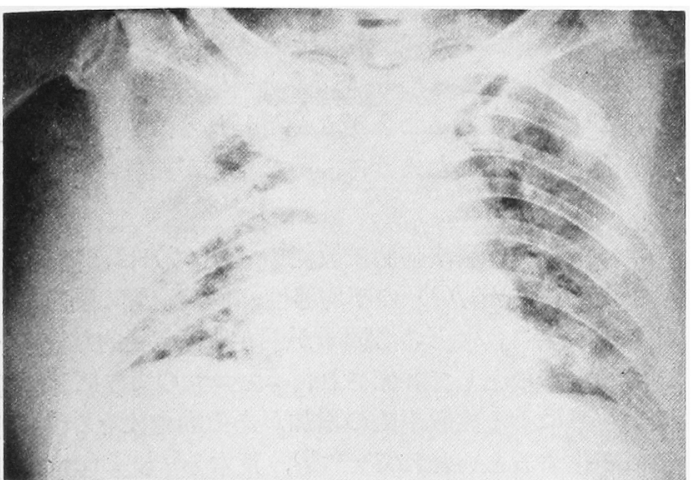

写真 5 死亡直前の胸部X線写真

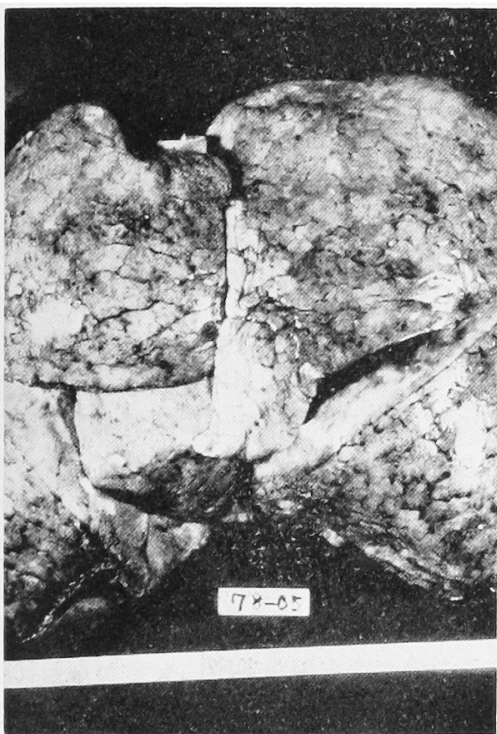

写真 6 剖検摘出肺

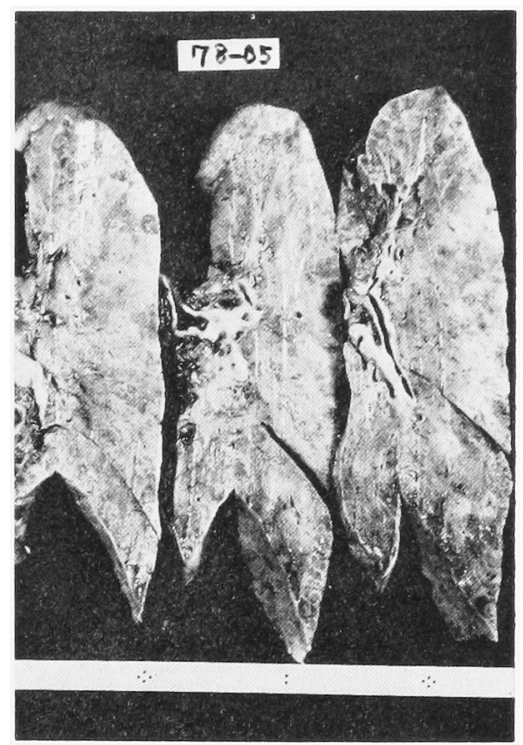

写真 7 左肺の固定後の割面

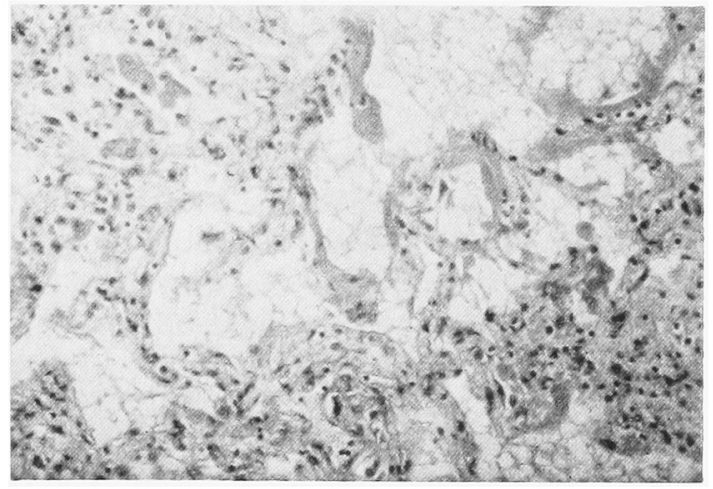

写真 8 剖検肺組織所見

考察

従来のブレオマイシン（以下 BLM と略す）の副作 用の 1 つに肺臓炎ないし，問質性肺線維症があることは よく知られ ${ }^{1 \sim 7)}$, 本症発生が BLM 使用上の制限因子の 1つになっている。諸家の報告をみると，その発生に及 ぼす因子として，年路，投与量，投与方法があり，高齢 者，特に肺に多少とも障害がある場合は高率に発生する といわれているが2，投与量，方法についてはその因果 関係は不明確で, 特に投与総量と発生頻度の間には相関 がないとする報告が多い,8,9) 一般的に肺障害の 進展機 序として, BLM が肺毛細管の endothelium に直接働 いて，その透過性をえ進させ，その結果， alveolar space と間質に浮属を生じさせて，さらに吸収障害が加わるこ 
とでいわゆる intra-alveolar fibrosis あるいは interstitional fibrosis に発展するといわれている5).この BLM の内膜における直接作用について，下里 ${ }^{3)}$ は，個体の hypersensitivity と薬剤（BLM）の基質变化作用，すな わち直接肺胞内膜を異型化する作用が関与するとしてい る。なお，このように肺障害を惹起する危険性をるつ抗 癌剂は BLM に限られたものではなく MMCなどでも その報告がある3)。今回，われわれが使用した NK-631 は動物実験で BLM より優れた抗腫瘍性を有し，かつ

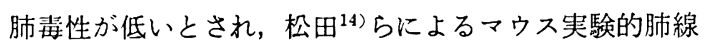
維症モデルを用いた NK-631，と BLM の肺毒性の比較 実験では, NK-631 はBLM に比べ, 線維化の発生頻 度は $1 / 3$, 程度は $1 / 4$ であることを組織学的に明らかに し, さらに肺のコラーゲン量の指標となるハイドロキシ プリン含量が BLM よりも少ないことを生化学的に証

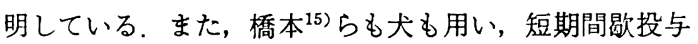
毒性研究により，低肺毒性を確認している，以上のこと 上り海老原ら ${ }^{16)}$ は， NK-631 は臨床上肺に対する副作 用に制限されること少なく使用される可能性があると述 べているが，臨床的に肺毒性を検討した報告は少なく， 今回のわれわれの検討も含め今後の課題である.

臨床的にはこのような場合の肺毒性を早期に予知した り予防する目的で, 呼吸器症状のチェックの他に, 肺機 能の変化にその指標を求めようとする試みが多くなさ れ, 各種肺機能検査, 特に肺活量 ( $\mathrm{VC})$, \%肺活量 ( $\%$ VC), $\mathrm{PaO}_{2}$, 一酸化炭素肺胞扗散能力 (DLCO) の異常 の意義が論じられている ${ }^{9 \sim 13,17,18)}$ 。前述したように，本 症の本態は血管を介した間質性の変化が主で, 非感染因 子により起こるものであるので, 機能上の障害は, 閉塞 性障害よりも肺コンプライアンスが減少するいわゆる拘 束性障害が主であることが予想される。なお，肺の拘束 性変化が生じた場合, 当然, VC, \% VC, MVV (最大 換気量）は低下をきたすと思われるが，冨田 ${ }^{9}$ は BLM 総投与量 $300 \mathrm{mg}$ 以内では有意な 低下はなかったとし, 荒本 ${ }^{8)}$ も VC が進行性汇低下する傾向はなく，VC 測 定のみでは肺障害早期予知の指標にはならないと報告し ている，また，MVVは患者の負担が大きいことや測定 誤差が大きいことから有力な指膘にはなり得ないとする 報告がある。しかし，一方では，VCを40人の患者で調 査し，BLM 投与量とは関倸なく，結果的に $50 \%$ 低下し たという Yagoda ら ${ }^{17)}$ の報告もあり，一概にその意義 を否定できないわれわれの NK-631 のデータでは結 果的に 7 例中 5 例が VC，\%VC とも低下したが，その 減少率は進行性に悪化しているとは限らず，NK-631 投 与中でも一時期改善しているものもあり，また NK-631 投与量との相関も得られなかった。 また，MVVは3 例 のみにしか調査できなかったため結論できないが， 3 症 例のそれぞれの VC の変化とあわせて考えてもすべて が相関しておらず著明な減少があるようには思えない。
ただし，閉塞性障害度を婊す1秒率の变化をみると， ほとんどが10\%以内の变化にとどまり，このことから NK-631 投与によっても BLM と同様に拘束性障害を引 き起こす傾向があることがらかがわれる，特に症例 4 で は，図7にも示したように，その变化が顕著に現れてい る.

次に, 一酸化炭素肺胞拡散能力 (DLCO) は, 換気量, 換気血流比 $(\dot{V} A / \dot{Q})$ の不均等性, 肺胞血管の膜因子之 肺毛細管血液量などの各因子が関与し，包括的な機能を 示唆するものとして評価され， fibrosis のように肺胞隔 壁の肥厚による拡散距離の增加がある場合はその值が鋭

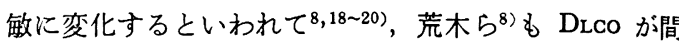
質の変化を早期に検出する手段として最も信頼性がある と報告している．今回のわれわれのデータでも 6 例中 5 例飞 $10 \%$ 以上の悪化がみられ，その変動率も VC, \% VC などの肺気量分画より大きく，肺内での間質の変化が裏 付けられたとしてょいであろう．以上のように肺機能検 査の結果だけでみると，NK-631 は臨床的に肺毒性を るつことが推察されるが，このように機能娭査上たけで 肺内の動態を評価するのにも問題がないわけではなく, 特にわれわれの取り扱ら口腔癌の場合は, 検査を行らに あたって比較的大きなマウスピースを装着しなければな らないことから，患者に少なからす負担を与えることに なり, 症例によっては測定が不可能になることがある。 特に老人ではこのような測定上の誤差が大く現れる可 能性もあり実際の肺機能を反映しないこともあるので, よく検討してから実施しなければならない，このことを 考えると， spirometor を用いた肺気量分画測定よりも， 患者の努力をさほど必要としない $\mathrm{PaO}_{2}$ 測定により肺機 能をとらえようとする試みは，ある程度の客観性が得ら れ，口腔癌の場合は有用な手段になるかもしれない，今 回，われわれは $\mathrm{PaO}_{2}$ 測定を行わなかったので，VC, \%VC，Dlco などの值の変化との相関は不明であるが, Comroe ${ }^{21)}$ が述べているよらに，DLCO が 50〜70\%に 低下しても，生体の $\mathrm{O}_{2}$ transfer に対する大きな予備力 のため，肺毛細管の血液は十分に oxygenationされう ることから， $\mathrm{PaO}_{2}$ の変化は $\mathrm{DLCO}$ の変化より少ないこ とが予測される。

次に, 胸部 X線写真上での変化として, 著明な異常像 がみられたものは, 先に述べた症例 4 と, 死亡症例の計 2 例であるが，写真上で線維性变化をとらえるのは mass lesion の診断などに比して困難であり，また，一 般に肺機能検査上での 異常值発現より time lag をおい て異常陰影の出現があるといわれていることから ${ }^{8)}$, 本 法だけで follow up していくのは危險と考える.

最後に, 死亡症例の肺剖検所見に沶いては，下里 ${ }^{33} か$ 要約した BLM fibrosis と同様の組織所見, すなわち, (1)肺胞上皮細胞の腫大, 異型化, (2)胞隔の小血管の抾張 と浮腫, びまん性の胞隔の炎症と線維化，(3)線維素に富 
む水腫液の肺胞腔内への貯留, 硝子様膜の形成, 浸出物 の器質化による肺胞内線維化，と一致する所見が得ら れ，NK-631 に基因する肺線維症の発現があったことを 確認した。

今回のわれわれの検討では，一応 NK-631 を BLM の投与方法，量に順じて与えたが，NK-631 の臨床的な 使用方法が十分に検討されていない現在，単純にその琵 性を BLM と比較検討すべきではないと考えるが，以 上述べたよらにわれわれの経験からすると，臨休的には BLM と同様に肺障害を起こす可能性があることは否定 できず，本副作用に対し安易に対処することは危険であ ると考える。

\section{結語}

1. 7 例の口腔領域悪性腫湟患者に, NK-631 を投与 し，その副作用の 1 つである肺障害の発現とその過 程 を，胸部X線写真および肺機能検査 (VC, \% VC, MVV, FEV1. 0/VC，Dlco）で検討した.

2. VC, \% VC, Dico に拈いて 7 例中 5 例の患者に 10\%以上の低下が認められた。 また，FEV1.0/VCに 恃変化が少なく，このことより肺の拘束性障害の発現が らかがわれた。

3. 急性肺炎にて死亡した症例を経験し，その肺剖検 所見では線維化がみられ，薬剤 (NK-631) 基因性の変 化であることを認めた。

4. 胸部X線写真上では 2 例（死亡症例を含む）に著 明な線維性変化がみられ，機能検查上の值と一致した。

5. NK-631 は臨床的に BLM と同様の肺線維症お よび間質性肺炎を惹起する危険性があり，本副作用に対 し安易に対処することは危険であるといら結論を得た。

稿を終えるにあたり，剖検症例についてその所見をご 教示いただいた富山市民病院検查部高柳尹立部長に深謝 いたします。

本論文の要旨は，昭和53年 9 月14日，第23回日本口腔 外科学会（於，盛岡）にて発表した。

\section{引用 文 献}

1）市川篤二, 他 : Bleomycin 副作用の統計的観察. ブレオ文献集 : 391969.

2) 近藤有好, 他: Bleomycin-pneumonitis の臨床 病理学的研究. 日胸 31: 1111972.

3）下里幸雄: 抗癌剈による肺障害。医学のあゆみ 73: 1151970.

4) 長浜交雄 : 原発性肺癌の Bleomycin 有効例と
肺線稚症併発例。ブレオマイシン研究会肺癌部 会誌 3: 131970 .

5）下里幸雄：BLM による肺線維症（剖検所見に ついて)．ブレオマイシン研究会肺癌部会誌 2 : 1241970.

6)田島 洋, 他：ブレオマイシンによる肺線維症 の 2 剖検例. 日胸 29: 3901970.

7) 田原 实, 他: Bleomycin 使用中著明な肺線䧽 像を呈した皮缯癌の1剖検例。日眴 29：174 1970.

8）荒木高明：ブレオマイシン肺葴咨早期発見の指 標としての肺機能検查. 癌と化学潦法 5: 573 1978.

9）冨田一夫，他：ブレオマイシンの肺機能に及沶 寸影掣。名医学 94: 11972.

10）白石晃一郎，他：プレォマイシン投与後の肺機 能検查成績。肺と心 19: 731972.

11）斎藤 隆, 他: ブレオマイシンの肺線維性変化 と肺機能. ブレオマイシン研究会肺癌部会誌 3: 2001970.

12) Pascual, R.S., et al.: Effects of bleomycin on pulmonary function in man. Amer Rev Resp Dis 108: 2111973.

13) Horowitz, A.L., et al.. The pulmonary changes of Bleomycin toxity. Diagnostic Radiology 106: 651973.

14) Matsuda, A., et al.: Fundamental and clinical studies on new bleomycin analogues. "Antitumor Antibiotics" in Recent Results in Cancer Research 63: 1911978 (Springer Verlag).

15）橋本芳昌, 他: 硫酸ペプレオマイシン (NK-631) の毒性研究 V.ビーグル犬における短期, 間歇 投与毒性. Jap J Antibiotics 31：837 1978.

16) 海老原和雄, 他: 硫酸ペプレオマイシン（NK631) の抗菌性, 抗腫場性, および肺線維化能 に関する基礎的研究. Jap J Antibiotics 31: 8721978.

17) Yagoda, A., et al.: Bleomycin, an antitumor antibiotic: Clinical experience in 274 patients. Ann Intern Med 77: 8611972.

18) Ogilvie, C.M., et al. A standardized breath holding technique for the clinical measurement of the diffusing capacity of the lung for carbon monoxide. J Clin Invest 36: 11975.

19）村尾誠，他：肺拡散量の正常値および肺疾患 患者における異常値の評価について，日本臨床 24: 1631966

20）望月政司，他：ガス拡散障害，呼吸と循環 15: 7551967.

21) Comroe, J.H.: Physiology of Respiration. 2nd Edition, Year Book Co, Cicago, 1974166. 